\title{
UNDERSTANDING EFFECTS OF INNOVATIVE AND COLLABORATIVE APPROACHES ON SUPPLY CHAIN PERFORMANCE
}

\author{
DOI: 10.17261/Pressacademia.2017.457 \\ JMML- V.4-ISS.2-2017(6)-p.125-142 \\ Hakan Demir ${ }^{1}$, Bülent Sezen ${ }^{2}$ \\ ${ }^{1}$ Gebze Technical University, Kocaeli, Turkey. hkn_dmr 87@hotmail.com \\ ${ }^{2}$ Gebze Technical University, Kocaeli, Turkey. bsezen@gtu.edu.tr
}

\section{To cite this document}

Acer, A and G. Yanginlar, (2017). The determınatıon of Turkısh container ports performance with TOPSIS multiple criteria decision making method. Journal of Management, Marketing and Logistics (JMML), V.4, Iss.2, p.125-142.

Permemant link to this document: http://doi.org/10.17261/Pressacademia.2017.457

Copyright: Published by PressAcademia and limited licenced re-use rights only.

\begin{abstract}
Purpose- Main goal of this paper is to perform an exploratory and empirical research on the interactions of collaboration and innovation elements that are presented in the literature; co-creation, service dominant logic, open innovation, negative entropy and entrepreneurship orientation. Moreover, this study aims to examine the effects of these elements on supply chain performance attributes (reliability, responsiveness, flexibility, costs and asset management).

Methodology- In order to understand the effects of innovative and collaborative dynamics on supply chain performance, prominent logistics service providers and firms with officially approved R\&D departments were surveyed.

Findings- This study provides evidence on strong relationships between supply chain performance and co-creation, SDL, and open innovation. One of the findings that grabs our attention is the remarkable effect of negative entropy on co-creation, SDL and open innovation. Moreover, according to results, negative entropy has the highest individual effect on supply chain performance in comparison with other collaboration and innovation elements.

Conclusion- This paper highlights the importance of innovative and collaborative dynamics in supply chain performance measurements. This research also provides evidence to supply chain performance literature by suggesting negative entropy as a powerful instrument of integration and preservation in supply chains.
\end{abstract}

Keywords: Supply chain performance, co-creation, open innovation, service-dominant logic, entrepreneurship orientation, negative entropy.

JEL Codes: M11, M19, L14, L25

\section{INTRODUCTION}

Businesses are today characterized by interlinked value creation processes between customers, firms and other actors. This interactive business reality puts pressure on firms to reconsider and improve their procedures to serve their customers in better ways (Karpen\&Bove, 2008). As for supply chains, the situation is not different. Madhani (2012) argues that the pressure on organizations prompt them to find new ways to create and deliver value to customers through supply chain management (SCM). Simatupang and Sridharan (2002) state that the main goal of a supply chain should eliminate sources which prevent members from obtaining optimum profit by delivering value to end customers, and this goal can be achieved through effectively collaborated supply chains.

Performance measurement systems are vital for evaluating the extent of success in today's competitive business environment. In this paper, performance measurement system of SCOR model introduced by Supply Chain Council (SCC) in 1996 is used to study the effects of collaboration dynamics. SCOR model is a cross-functional framework which integrates 
business processes via performance measurement. Its standard framework provides easy communication and it is a useful tool for the top management to achieve firms' desired performance. SCOR utilizes five fundamental supply chain performance attributes: reliability, responsiveness, flexibility, costs and asset management (Jothimani\&Sarmah, 2014).

Brief descriptions of these performance attributes are given below (Stephens, 2001).

Reliability: Supply chain performance in delivering the correct product, in the correct quantity, to the correct place and customer, at the correct time, in the correct condition, with the correct documentation.

Responsiveness: The velocity at which the supply chain respond to the customers' needs.

Flexibility: The agility of a supply chain in adapting to market changes to preserve or improve competitive advantage.

Costs: The costs performance management regarding supply chain operations.

Assets: The effectiveness in usage of an organizations' assets to support demand satisfaction.

Beyond single organizations, supply chains now compete with each other to find new ways in delivering better value through better collaboration. There is a consensus which implies the performance improvement of supply chains through collaboration and innovation (Seifert, 2003; Bigliardi et al. 2010; Lin et al. 2010; Ramanathan et al., 2011; Liao\&Kuo, 2014). Thus, it can be inferred from the literature that collaboration and innovation elements positively affects supply chain perfomance. Those elements that used in this research are entrepreneurial orientation, negative entropy, co-creation, service-dominant logic (SDL) and open innovation. Succint explanations of these notions are given in the following paragraphs.

Strategic orientation literature brought out a new concept "entrepreneurial orientation" (EO) as one of the components of strategic orientations (market, learning, service and entrepreneurial) (Zhou et al. 2005). EO has become a major subject of the entrepreneurship and strategic management literature (Covin et al. 2006; Anderson et al. 2009). In this context, entrepreneurial strategy making processes are considered as a path in fulfilling firms' organizational purposes and creating competitive advantage (Rauch et al. 2009). Within the context of supply chains, entrepreneurial orientation prompts supply chain actors to innovate through collaboration.

Negative entropy is an important capability which provides compulsory collaboration and innovative steps for firms. It is an important value for an organization in preventing infollution and creating open, interactive environments for supply chain actors. In open social systems, organizations can convert their entropy into negative entropy by importing resources from the environment and decelerate their dissolution or termination processes (Kast\&Rosenzweig, 1974).

The interaction between customers and firms has become the stimulus for the creation and extraction of value. The transformation of the business environment strongly focuses on co-creating value with customers. (Prahalad\&Ramaswamy, 2004). Markets rapidly shift from value-adding to value co-creation, value-delivering to value propositions and products to experiences (Dong et al. 2008).

Service dominant logic was introduced to literature by Vargo\&Lusch (2004). It basically offers an alternative view to goodsdominant logic in a way which integrates market actors and final customers for a collaborative, system-based value creation. (Vargo et al. 2008). Previous studies confirm and emphasize the importance of this integration (Karpen\&Bove, 2008; Merz et al. 2009; Nam\&Lee, 2010).

The idea of open innovation, which was presented by Chesbrough (2003), defines a system that corporate innovation activities are executed in an interactive open environment rather than the traditional vertically integrated model (West et al. 2014). The central idea behind open innovation is that enterprises ought not to rely on their own research entirely and attenuate their scope, but instead they should import external inventions, knowledge, processes and contributors into development processes and joint research (Užienè, 2015).

In this study, we investigated effects of those dynamics on the supply chain performance, interactions between them and individual effect of each variable on supply chain performance. This paper is composed of five sections. After the introduction, the theoretical background of the proposed model is presented. Afterwards, information on sample and measurement instrument is given in the research methodology section. In the fourth section, results are demonstrated including demographic dispersion. In the discussion and conclusion section, research implications are discussed and final remarks about the limitations and future research are made.

\section{LITERATURE REVIEW AND HYPOTHESIS}

Entrepreneurial firms adopt an aggressive and proactive focus on innovations to encounter intimate customer needs (Atuahene-Gima\&Ko, 2001). Additionally, entrepreneurial firms lead the efforts to change the institutional environment by infusing new rules, routines, and values into social structures (Battilana et al. 2009). 
Entrepreneurial orientation involves experimentation with promising new technologies, a willingness to seize new productmarket opportunities and a predisposition to undertake risky ventures (Lumpkin\&Dess, 1996; Kreiser et al. 2002). Lumpkin and Dess (1996) also state that entrepreneurial orientation closely relates to aspects in the innovation literature.

Chen et al. (2012) give evidence on entrepreneurial orientations which positively and simultaneously affect two types of core organizational value-creating capabilities: exploitative and exploratory capabilities. Further, Zhou et al. (2005) found that EO is positively related to innovations. Prior research has also accentuated EO as a fundamental antecedent for achieving innovation success (Zhou et al. 2005; Lisboa et al. 2011) and for capturing firm performance (Rauch et al. 2009).

SDL requires continuous monitoring between the company's customers and resources. Lamberti and Paladino (2013) argue that a possible link may be established between SDL and EO, because of its interactive nature (Lumpkin\&Dess, 1996). Through SDL, Lamberti and Paladino (2013) also point to customers' active participation in value creation (Vargo\&Lusch, 2004). Placing customer centricity and SDL in the bottom, firms construct strategies through their interaction with the customer and additionally through the empowerment of employees in the use of interface resources (Galbraith, 2005). These are the key elements for both SDL and entrepreneurship orientation. Thereby, the relation between SDL and EO stands in their interactive, resource focused and participative nature. Customer centricity and co-creative approach to value generation and the focus on resources in unison enable a firm to create value for both the customer and the firm (Lamberti\&Paladino, 2013).

Callaway and Dobrzykowski (2009) accentuate service-oriented entrepreneurship as a good application of SDL. In their paper, it is argued that SDL centered view of entrepreneurship may be useful in unlocking new opportunities previously left out by conventional goods dominant view. Read et al. (2009) and Sarasvathy (2008) integrate the concepts of entrepreneurship and SDL by describing the cognitive science-based logic of entrepreneurial expertise as "effectuation". Effectual entrepreneurs focus on intangible resources, the co-creation of value (Vargo\&Lusch, 2004; Read et al. 2009; Callaway\&Dobrzykowski, 2009).

\section{H1: Entrepreneurship Orientation positively affects Co-Creation.}

H2: Entrepreneurship Orientation positively affects SDL.

H3: Entrepreneurship Orientation positively affects Open Innovation.

Entropy is a tendency where properties of a system become increasingly unreliable in predicting the final state of a system that is subject to some process. In contrast, negative entropy (also known as "negentropy") is a force that seeks to stabilize a system into a steady and predictable state (Grinberg, 2007). Schneider and Somers (2006) describe the cycle of entropy and negative entropy as the leading force of disorganization or death. In order to survive, negative entropy is acquired by storing energy from the environment.

In a closed system, the change in entropy must always be positive. However, in open biological or social systems, entropy can be attenuated and may even be transformed into negative entropy because, the system imports resources from its environment (Kast\&Rosenzweig, 1974). In fact, open systems, such as managerial or social organizations, can survive indefinitely because they interact with their environment to achieve negative entropy by importing more energy than they export (Peery, 1975). In order to comprehend the study further system theory should be explained. A particular system which imports inputs from its external environment uses these inputs through its processes to transform them into outputs, and finally exports to its external environments. Natural, human, and financial resources are all fundamental organizational inputs. Organizational throughput processes include research and development, production, distribution, marketing and administration. Organizational outputs include products, services by-products and even waste (Starik\&Rands, 1995).

As one of the characteristics of an open system proposed by Katz and Kahn (1978), negative entropy prompts social organizations to improve their survival position and to acquire in their reserves a convenient margin of operation. Following these crucial facts about negative entropy, we propose that negative entropy in open system theory can also be an essential driver of complex system such as a supply chain.

During the hypothesis development we chose this vital element, negative entropy, as an independent variable and conclude that even an exploratory research might yield satisfactory results, since negative entropy is about preserving and improving. We adapted the scale developed by Gok (2014), corrected items and their wordings to reflect supply chain preservation and performance concepts. Consequently, it is proposed that negative entropy which sustains a supply chain is positively and closely related with co-creation, SDL and open innovation.

H4: Negative Entropy positively affects Co-Creation.

H5: Negative Entropy positively affects SDL.

H6: Negative Entropy positively affects Open Innovation. 
Cooperative value creation can be defined as the processes in which the capabilities of partners are combined so that the competitive abilities of either the hybrid or one or more partners is improved (Borys and Jemison, 1989). In the traditional process of value creation, consumers were kept outside the firm. Value creation processes had occurred especially inside the firm and outside of the markets. (Prahalad\&Ramaswamy, 2004). During this traditional phase of value creation, consumers were always considered as reductionists. However, multifaceted co-creation, -as enabled by the internet and other instruments-, has made consumers a subject worthy of investigation in an integrated chain of production (Zwass, 2010).

By supplying customers with goods, services and information, the supplier is fundamentally a value creator. Co-creation opportunities that suppliers possess can present strategic options for value creation (Payne et al. 2008). Grönroos (2008) argues that by producing value-supporting resources the firm actually facilitates value creation. By interacting with its customers' processes, firm becomes a value facilitator and the co-creator of the value. During the interactions caused by co-creation, both parties are active in a learning process and influence each others' actions and perceptions (Ballantyne, 2004; Ballantyne\&Varey, 2006). Value cannot be distributed or delivered by firms but rather its actualization can only be supported and facilitated (Vargo\&Lusch 2004). Further, Mascarenhas et al. (2004) suggest that customers should be involved at all stages of value chain, through customer-value-chain involvement (CVCl) model.

However, in the area of supply chain relationships where customers are defined as the next member of supply chain, these relationships are transformed into B2B partnership-like nature as a result of co-creation. Goffin et al. (2006) point to several important literature implications of these relationships; advantages including better quality, lower costs and reliable delivery. Instead of competing, members of a supply chain can expand the value as well as their share from the pie through the co-creation processes as shown in Figure 1.

Figure 1: Co-Creation in Supply Chain (Dyer, 2000)

\section{Traditional Relationship \\ Focus on splitting the pie}

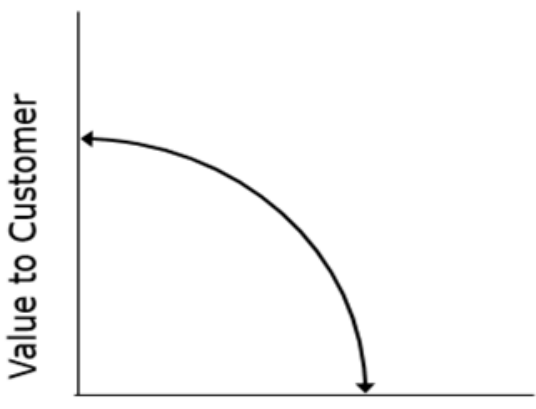

Value to Supplier
Extended Enterprise

Focus on expanding the pie

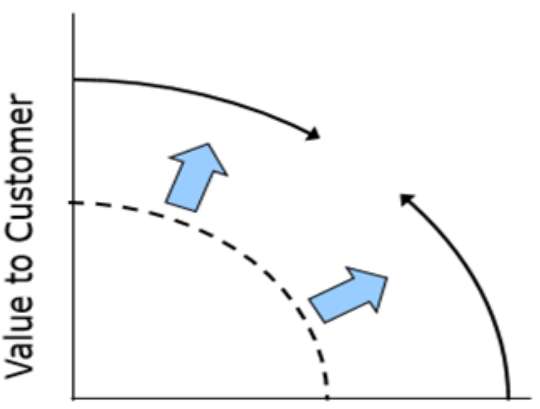

Value to Supplier

Bowersox et al. (2002:590) put emphasis on the unity of the whole supply chain and stress that supply chain members must have shared responsibility for achieving value-creation process. Firms must carefully consider their visions, strategies, and operational capabilities while selecting partners. If these members could become partners of the supply chain, also entitled as a value chain, (Flint\&Mentzer, 2006) through spreading the risks and rewards, they would reduce duplication, redundancy and other kind of disruptions, and maintain cooperative value creation.

Following the literature about value co-creation and empirical study of Lin et al. (2010) on Taiwanese high-tech companies which operate global supply chains, we believe and propose that supply chain performance is positively influenced by value co-creation.

\section{H7: Value Co-Creation positively affects Supply Chain Performance.}

In 2004, Vargo and Lusch (2004) introduced SDL to academic and managerial community. Their theory became a game changer in marketing discipline. SDL broadens the perspective of exchange and value creation and implies that all social and economic actors engaged in an exchange (e.g., firms, customers, etc.) are service-providing, value-creating enterprises (Vargo\&Lusch, 2004).

SDL is an alternative to goods-dominant (G-D) logic and allows managers to view and understand a business better through a service-based lens (Lusch et al. 2006). From the Goods-Dominant Logic perspective, services are just add-ons for goods. 
On the other hand, service-dominant logic views service, instead of goods, as the focus of economic and social exchange. Goods are just appliances for service provision from SDL perspective.

In SDL theory, market actors collaborate and interact with the capabilities and competencies of the other parties that render service. SDL forms the basis for a collaborative, system-based view of value creation, which includes other market actors and final customers (Vargo et al. 2008). Therefore, SDL integrates the secular distinction between services and goods in terms of benefit provision for the whole system (Vargo\&Lusch, 2004). This integration draws its power from coherently explaining and unifying the service role of interacting partners and involved mediators such as goods (Karpen\&Bove, 2008).

The SDL stresses on the joint value creation of firms and customers (Finney et al. 2011). According to Lusch (2011), SDL replaces the supply chain with a network concept that is referred to as a service ecosystem. In a service ecosystem actors make value propositions to each other for adding or delivering value via information technologies. Lusch (2011) proposes robust implications on the expansion of a service ecosystem consistent with principles of SDL through information technologies. On one hand, knowledge -as the most fundamental operant resource for competitive advantage- is an essential source for implementing SDL (Lusch et al. 2007). On the other hand, information is considered as the most significant part in supply chain relations as Gunasekaran and Ngai (2004) view information technologies as a nerve system for SCM that enables actors to more intellectually respond to each other.

SDL approach actually inspired us to reconsider our conceptual model. Because of the highly integrated system offered by $\mathrm{SDL}$, it became the nucleus of the research structure for explaining the supply chain relationships. With all that said, we believe that supply chain relations and performance are closely correlated with service dominant logic.

\section{H8: SDL positively affects Supply Chain Performance.}

Innovation offers a significant driving force and a unique opportunity to address mounting economic pressure, diminishing resources, and environmental challenges. Open innovation, on the other hand, describes how firms innovate through interacting with external organizations. Open innovation was proposed by Chesbrough (2003) but was recently defined as the use of purposive inflows and outflows of knowledge to accelerate internal innovation and expand the markets for external use of innovation (Chesbrough, 2012). In other words, boundaries between firms and their surrounding environments are rapidly becoming invisible which allows innovations to expand and improve (Van Lancker et al. 2016).

Chesbrough (2003) state that internal innovation strategy is reaching its limits and firms now seek new ways to engage in open innovation. They spryly pursue opportunities to collaborate with suppliers, customers and even their direct competitors (Inauen\&Schenker-Wick, 2011). Embracing the fact that all brilliant R\&D personnel is not working for them, organizations now view partnerships as opportunities to acquire new technologies, further use these relationships to absorb skills and diffuse new knowledge (Hamel et al. 1989). According to Pilav-Velić \& Marjanovic (2016), open innovation paves internal and external paths to markets for firms, boosting their value creation and innovation performance in return.

Literature suggests that open innovation is essential for firms in gaining competitive advantage in terms of innovation (Saguy and Sirotinskaya, 2014; Traitler and Saguy, 2009). Yet undoubtedly, open innovation paradigm still poses a number of challenges regarding the identification of several relationships. We believe that supply chain performance improvement is one of these challenges that organizations should circumvent. According to Handfield et al. (1999), integration of suppliers in collaborative innovations can provide significant benefits, which include achieving reduced cost at product development, reduced time spent and decreased risk of failure. Additionally, several studies on the subject state that supplier-customer joint innovations can allow them to achieve higher supply chain performance (Shamah\&Elsawaby, 2014; Fawcett et al., 2012; Bigliardi et al. 2010; Ulrich\&Ellison, 2005). In their empirical study, Azadegan\&Dooley (2010) provide evidence on the positive effects of innovativeness of the supplier on the performance of the manufacturer. In light of these studies, we posit open innovation as a collaborative effort which firms ought to implement in improving their supply chain performance.

H9: Open Innovation positively affects Supply Chain Performance. 
Figure 2: Conceptual Framework

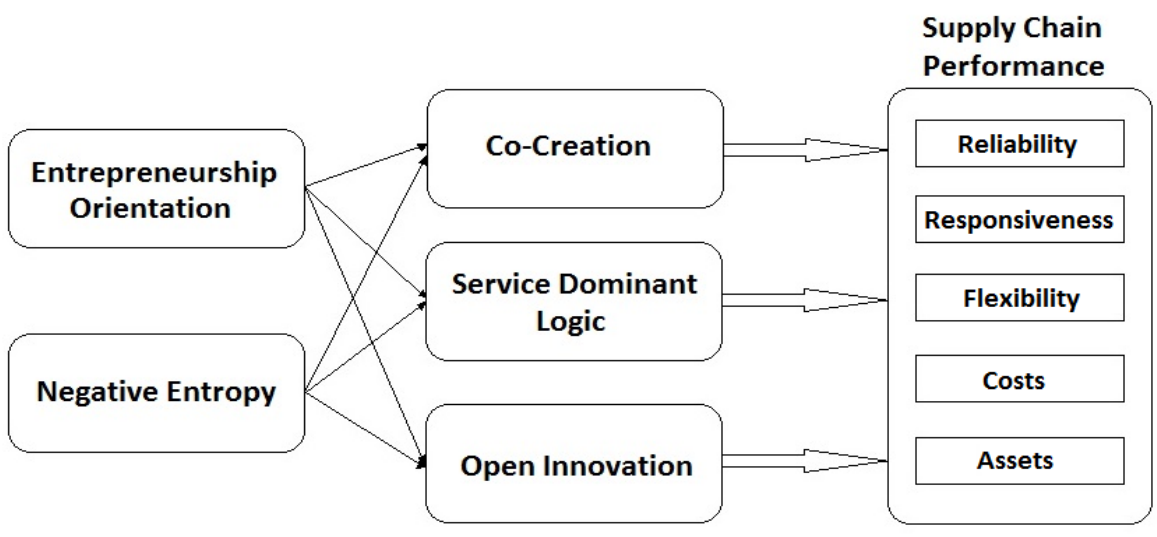

\section{DATA AND METHODOLOGY}

\subsection{Sample and Data Collection}

While designating the target population, firms with R\&D departments and logistics service providers and that reserve the highest budget to these R\&D departments were chosen. As cooperation and innovation notions are the baselines of this research, companies with high-budget allocated R\&D departments are evaluated to fit better to these baselines. While acquiring the target population two official firm lists are used. The first list is approved by Turkish Ministry of Science, Industry and Technology shows 233 R\&D centers from 216 companies. The second list was officially acquired from Turkish Exporters' Assembly, which shows 250 firms that reserve the highest budget to their R\&D departments. 375 companies were pooled from the two lists mentioned. Additionally, 15 leading logistics service provider companies in the sector with substantial capacity were added. In total, 390 firms were designated as the target population to which questionnaire was applied via face-to-face interviews, e-mail or an online-survey.

In total, 174 firms responded with 180 samples, resulting in a high response rate of \%45. After discarding the five incomplete and improperly responded surveys from three firms and excluding multiple responses from four firms, 171 observations remained and were subjected to analysis. Hair et al. (2010:635) state that minimum 150 sample size is needed for models with less than seven constructs and communalities higher than 0.5. Our structure has six constructs with communality values varying between 0.523 and 0.843 . As a result, 171 observations in this study will be adequate.

On the other hand, sample is subjected to wave analysis to ensure that non-response bias is not an issue in this research (Lewis et al. 2013; Halbesleben\&Whitman, 2013). Data gathered from early 50 and late 50 responders were tested with ttest. Results show no significant difference between the groups, meaning that sample is not contaminated with nonresponse bias. As items measured with the data were taken from the same source (Avolio et al. 1991), the sample was tested with Harman's single factor test (Harman, 1976) in order to make sure that the data is free from common method variance. If common method bias is present, single factor will emerge from factor analysis of all the items (Podsakoff\&Organ, 1986). The unrotated factor solution showed that no single factor explains the majority of the variance and the first factor accounted for $28 \%$ out of the $68.3 \%$ explained variance. Consequently, results suggest that common method bias will not be a problem in this study.

\subsection{Measurement Instrument and Measures}

In order to gather data from the sample group, two-section questionnaire was used as a measurement instrument. First part of the survey requires personal information of the responder. Second part involves the items regarding the scales of this study. Participants were required to answer to the first five constructs' items according to the supply chain their firm operates in via 5-likert scale ranging from, "1-strongly disagree" to "5-strongly agree". For the dependent construct "supply chain performance", participants answered item questions considering their firms' performance in following 5-likert scale: 1 for "strongly dissatisfying" and 5 for "strongly satisfying".

Scales used as independent and mediating variables were adapted to research needs or were directly taken from previous studies of Jiang et al. (2014), Dibrell\&Moeller (2011), Lin et al. (2010) and doctoral thesis of Gok (2014). One question is 
excluded from the "SDL" scale after preliminary test results to prevent disruptions and sixth question is added to summarize the notion.

Mediating variable "Open Innovation" is developed by the authors of this study in order to specifically measure organizations' tendency to practice innovation beyond their own boundaries. During the scale creation, we benefited from the study of Chesbrough (2003) who originated open innovation, and studies of Pilav-Velić \& Marjanovic (2016), Yamazaki et al. (2012) and Lichtenthaler (2008) which mainly examine open innovation through a practice aspect.

In order to reach and determine the metrics of supply chain performance, contemporary Supply Chain Operations Reference (SCOR) model is taken as the basis while preparing the dependent variable. Although some authors add profitability and effectiveness into composure (Bolstorff, 2002), Supply Chain Performance measurement mainly falls into five performance attributes which are reliability, responsiveness, flexibility, costs and assets (Stephens, 2000; Theeranuphattana\&Tang, 2007; Kocaoğlu et al. 2013; Jothimani\&Sarmah, 2014; Sillanpää, 2015). These characteristics supply chains can be analyzed and evaluated against other supply chains with competing strategies (Najmi\&Makui, 2012). Hence, we developed items that address these five attributes the best. 45 items and six scales with their factor loadings, means and standard deviations are shown in Appendix 1.

\section{FINDINGS AND DISCUSSIONS}

\subsection{Sample Characteristics}

According to the characteristics of the sample shown in Appendix 2,76\% of the participants are male and $81.9 \%$ are aged between 26 and 45 . Respondents who work as an engineer, specialist, chief or low-level manager compose $91.5 \%$ of the total sample. $93 \%$ of the participants have a bachelors or masters degree and $88.2 \%$ have a managerial role.

Along with the characteristics stated, survey also requested information from participants about the firm they are working for. There are several issues that need to be underscored. $67.8 \%$ of the respondents are working in a facility which hosts more than 250 personnel and $\% 74.3$ work in a firm that has been operating for more than 20 years. Additionally, $75 \%$ of the participants state that they work in a manufacturing firm. Detailed information on sample characteristics of the sample is shown in Appendix 2.

\subsection{Validity and Reliability}

Discriminant and convergent validity analysis were conducted to test the validity of variables. Internal consistencies of measures were examined with composite reliability and cronbach alpha values. All tests were conducted on Warppls 5.0 and outcomes are shown in Table 1.

As for reliability, Cronbach's alpha (CRA) and composite reliability (CR) values equal to or higher than 0.7 are considered adequate (Hair et al., 2010:123; Bagozzi\&Yi, 1988). According to reliability test results shown in Table 1, CR and CRA values are over 0.7 for all the variables indicating reliability of the study.

In order to assess convergent validity, average variance extracted values were examined. Henseler et al. (2009) state that 0.5 is the threshold value for average variance extracted(AVE). Table 1 depicts that all variables' AVE values except supply chain performance' are higher than 0.5. Although it is lower than the threshold value, it was included in the structure because it meets the other requirements of validity and reliability tests as well as its contributions to the research. For the evaluation of discriminant validity, the Fornell\&Larcker criterion was used. In order to achieve discriminant validity, square root of AVE value for each construct ought to be higher than all of its correlations with other constructs (Fornell\&Larcker, 1981). Table 1 depicts that in all cases, square roots of AVEs are higher. Thereby, it can be concluded that there is discriminant validity between all the constructs.

Table 1: Reliability and Validity Tests

\begin{tabular}{lccccccccc}
\hline \multirow{2}{*}{ Variable } & $\begin{array}{c}\text { Cronbach } \\
\text { Alpha }\end{array}$ & $\begin{array}{c}\text { Composite } \\
\text { Reliability }\end{array}$ & AVE & & \multicolumn{6}{c}{ Correlation Between Variables and Square Root of AVES } \\
\cline { 6 - 10 } & .863 & .908 & .711 & .843 & & & & & \\
\hline E.O. & $.8 . O$. & N.E. & C.C. & S-D L. & O.I. & S.C.P. \\
N.E. & .861 & .893 & .546 & .348 & .739 & & & & \\
C.C. & .784 & .853 & .537 & .243 & .507 & .733 & & & \\
S-D L. & .812 & .865 & .517 & .233 & .521 & .385 & .719 & & \\
O.I. & .851 & .900 & .691 & .275 & .354 & .391 & .320 & .831 & \\
S.C.P. & .926 & .935 & .432 & .311 & .558 & .330 & .435 & .287 & .657 \\
\hline
\end{tabular}

Note: Numbers shown in bold are Square Root of Average Variance Extracted of each item. 
Reliability and validity reflect the trustworthiness and quality of a qualitative research (Golafshani, 2003). In our study, all the reliability and validity test results returned favorable values for the research.

\subsection{Structural Model Test Results}

Structural equation was solved with partial least square (PLS) method via Warppls 5.0 statistical program (Kock, 2015). PLS operates on a principal component analysis basis, aimed at explaining the alterations in constructs in a particular model. PLS has the advantage of predicting all individual element loads and path coefficients and also prevents from incoherent and biased parameter predictions (Chin, 1998). Overall fit results presented by program are shown in Table 2.

Table 2: Overall Fit Results

\begin{tabular}{lcccc}
\hline Fit Definitions & Results & Acceptable Range & Reference \\
\hline Average path coefficient (APC) & $0.267^{* *}$ & & \\
Average adjusted R-squared (AARS) & $0.249^{* *}$ & & & \\
Average block VIF (AVIF) & 1.135 & acceptable if $<=5$, ideally $<=3.3$ & (Hair et al., 2010) & (Hair et al., 2010) \\
Average full collinearity VIF (AFVIF) & 1.493 & acceptable if $<=5$, ideally $<=3.3$ & (Wetzels et al. 2009) \\
Tenenhaus GoF (GoF) & 0.385 & small $>=0.1$, medium $>=0.25$, large $>=0.36$ & (We
\end{tabular}

Note: "**" indicates $\% 01$ significance

Quality indices implicate that model is fit. Average path coefficient and average adjusted R-square values are significant under 0.01 level. Multi-collinearity can be an issue if VIF values are higher than 3 (Cenfetelli\&Bassellier, 2009; Hair et al., 2010:200). Average block and average full collinearity VIF values are under the threshold value of 3 . Furthermore, according to WarpPIs full collinearity VIF outputs, each variables' VIF values are below 3 and ranging between 1.196 and 1.972 , meaning that constructs are free of multi-collinearity. The Goodness-of-Fit is an index for validating the PLS model globally (Tenenhaus et al., 2005). In this study, Gof index returned 0.385 value indicating excellent model fit.

Coefficient results returned from structural equation modeling test are demonstrated in Table 3. According to the results, all the hypothesis except $\mathrm{H} 1$ and $\mathrm{H} 2$ are accepted. $\mathrm{H} 1$ and $\mathrm{H} 2$ hypotheses are rejected because the relationships they represent have beta coefficients lower than \%10 significance. Negative entropy has remarkable impacts on co-creation, SDL and Open Innovation with $0.51,0.51$ and 0.33 beta coefficient values, respectively. Furthermore, SDL, with a meaningful beta coefficient of 0.33 , has a dominant effect on supply chain performance compared to its counterparts.

Table 3: Results of the SEM

\begin{tabular}{lll}
\hline Direction of Effect & Beta Coefficient & Hypothesis \\
\hline Entrepreneurship Orientation $\rightarrow$ Co-Creation (H1) & $0.09^{*}$ & Rejected \\
Entrepreneurship Orientation $\rightarrow$ SDL (H2) & $0.08^{*}$ & Rejected \\
Entrepreneurship Orientation $\rightarrow$ Open Innovation (H3) & $0.22^{* * *}$ & Supported \\
Negative Entropy $\rightarrow$ Co-Creation (H4) & $0.51^{* * *}$ & Supported \\
Negative Entropy $\rightarrow$ SDL (H5) & $0.51^{* * *}$ & Supported \\
Negative Entropy $\rightarrow$ Open Innovation (H6) & $0.33^{* * *}$ & Supported \\
Co-Creation $\rightarrow$ Supply Chain Performance (H7) & $0.19^{* * *}$ & Supported \\
SDL $\rightarrow$ Supply Chain Performance (H8) & $0.33^{* * *}$ & Supported \\
Open Innovation $\rightarrow$ Supply Chain Performance (H9) & $0.14^{* *}$ & Supported \\
\hline
\end{tabular}

Note: Path coefficients with "***" indicate \%01 significance, "**” \%05 significance and "*” \%10 significance.

In addition to structural equation modeling presented above, effects of innovative and collaborative dynamics on five key performance metrics of SCOR were individually measured in order to acquire more intrinsic understanding on the matter. In Figure 3, individual effects of Entrepreneurship Orientation, Negative Entropy, Co-Creation, SDL and Open Innovation on SCOR elements can be seen. Results acquired will be discussed in the next section. 
Figure 3: Individual Effects on SCOR Elements

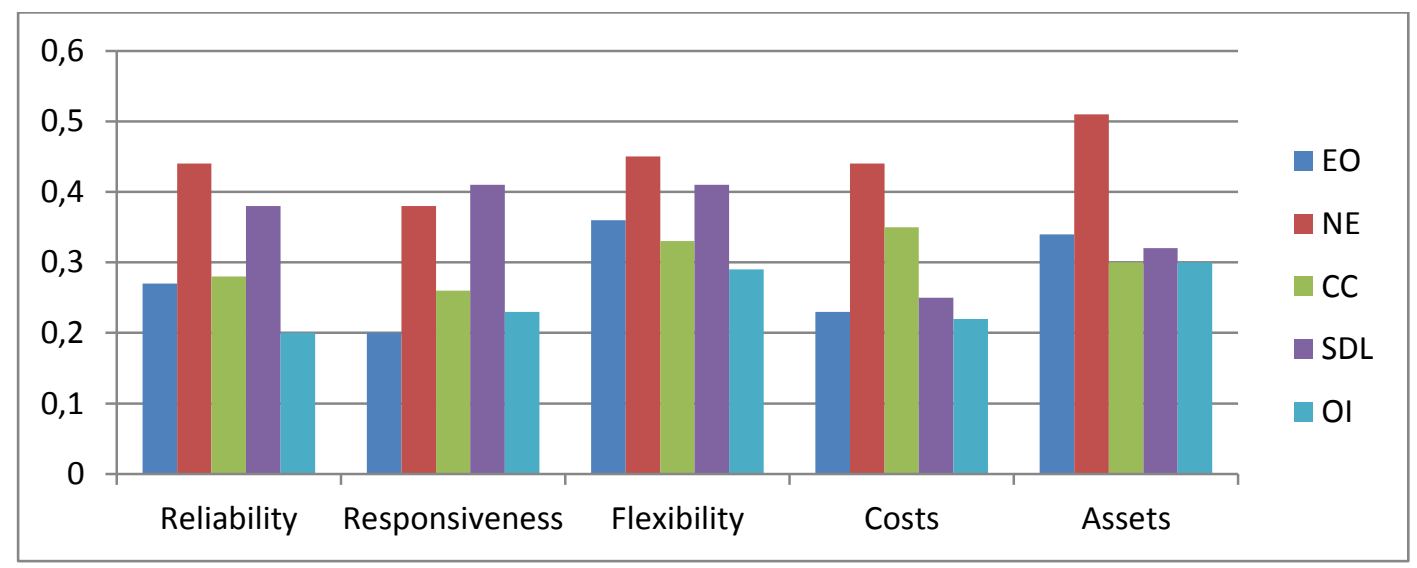

\subsection{Discussions}

Supply chains reach their intended goal if they are closely coordinated as a whole (Waters, 2010:4) and innovation becomes their routine (Christopher, 2011:212). In 1996, Supply Chain Council (SCC) introduced a performance measurement model termed as SCOR to observe this coordination and proposed five performance metrics. This paper does an exploratory research on several collaboration and innovation elements and their effects on these supply chain performance metrics: reliability, responsiveness, flexibility, costs and asset management. Results show that supply chain performance is abundantly affected by these collaboration and innovation dynamics.

The effect values of Co-creation, SDL and open innovation on supply chain performance are as follows: $0.19,0.33$ and 0.14 , respectively. Co-creation effect $(\beta=0.19, p<\% 0.01)$ on supply chain performance derived from structural equation is congruent with Lin et al. (2010) in which 0.21 beta coefficient was acquired from the research made on Taiwanese hightech firms. Another study by Ren et al. (2015) also points to a strong effect towards partnership quality. Work of Ren et al. (2015) is beneficial to mention at this point because, supply chain members are actually partners rather than suppliers or customers. $S D L$ also returned a significant beta coefficient value $(\beta=0.33, p<\% 0.01)$. Comparing to the other elements used in the model, SDL represents a dominant antecedent of supply chain performance. In our notion, what makes SDL stand out lies in its long-term usage and its easily deductive and measurable nature. Another explanation for SDL's precedence might be that firms perceive customer satisfaction as an essential aspect of continuity of their existence. Conversely, open innovation has a relatively less impact on supply chain performance $(\beta=0.14, p<\% 05)$. We believe the main reason for this result is that open innovation has not found itself adequate application areas among the organizations. In addition, firms may perceive open innovation as perfection rather than a prerequisite. Our study has similar results compared to the work of Bigliardi et al. (2010) who made research on Italian food machinery industry. According to the results, H7, H8 and H9 hypotheses are accepted.

In this study, interactions between negative entropy, entrepreneurship orientation and co-creation, SDL, open innovation were examined as well. According to structural equation modeling results, entrepreneurship orientation has beta coefficient values of $0.09,0.08$ and 0.22 for co-creation, SDL and open innovation, respectively. $\mathrm{H} 1$ and $\mathrm{H} 2$ hypotheses are rejected because entrepreneurship orientation had no significant effect on co-creation and SDL. On the contrary, but not surprisingly, $\mathrm{H} 3$ hypothesis is accepted for its significant effect of $0.22(\mathrm{p}<\% 0.01)$. From these results it can be deduced that entrepreneurship orientation is focused on innovation rather than collaboration. Last but not least, negative entropy returned enormous coefficient results from structural equation calculations. All less than 0.01 significance level, 0.51 for cocreation, 0.51 for SDL and 0.33 for open innovation are the coefficients of negative entropy. Co-creation, SDL and open innovation are concepts that intertwined with partners, concerning self-renewal. Because negative entropy is about environmental interaction and self-renewal, showing robust relation of negative entropy to these concepts is an ineluctable result.

Lastly, individual and detailed effects of innovative and collaborative dynamics on supply chain performance attributes were examined. Couple of implications arise from the derivations shown in Figure 3. First and the foremost issue is the outstanding impact of Negative Entropy on Supply Chain Performance attributes. According to the results, organizations that embrace this concept will undoubtedly operate their supply chains efficiently. Second issue is that why SDL stands out for flexibility, responsiveness, reliability and not for assets, costs. Assets and costs are rather internal performance issues which firms resolve without disruptions from environment. But flexibility, responsiveness and reliability performance 
metrics are mostly external issues which firms often interactively, innovatively or collaboratively address. We contend that this may be the reason why SDL's effects vary in that manner. Another implication is that the open innovation has a lower impact comparing to other items. The reason for this low result might be that it is rather a new concept in industry and commerce environments, and that the members of the supply chain are often hesitant to utilize open innovation due to security concerns.

\section{CONCLUSION}

Fundamental motivation of this paper is to discover how innovative collaboration dynamics affect supply chain performance. We implemented the questionnaire on an exclusively-selected sample, in order to acquire best results. Cocreation, SDL, entrepreneurship orientation and negative entropy scales were taken and adapted from the literature. Open innovation and supply chain performance scales were developed by researchers.

The model proposed in this paper and results derived from calculations provide several academic and managerial implications. First of all, this study approaches negative entropy as a vital element in supply chain operations. Besides, this paper contributes to literature by presenting a framework in which several innovation and collaboration dynamics are connected to supply chain performance unlike any other previous research. By bringing these concepts together, this research paves a new direction for empirical research on supply chain performance. According to structural equation results, co-creation and SDL have substantial impact, open innovation has medium impact on supply chain performance. An interesting finding is the superior influence of negative entropy on these dynamics. We believe that these concepts, negative entropy in particular, are important candidates of future supply chain performance studies.

As stated in the first two sections, innovation and collaboration are crucial for supply chains. This study confirms their importance congruently both with its findings and with a relatively high response rate of $\% 45$, prompting organizations to apply innovation and collaboration in daily supply chain operations. We assert that supply chains paying attention to innovation and collaboration will improve in performance. We hope that this paper will be helpful for both academicians and practitioners in improving and extending their work further.

On the other hand this paper has some limitations. First of all, this research was applied on a sample which is comprehensive but limited to organizations with R\&D departments. The main reason behind this exclusive sample selection is the thought that these organizations could more accurately perceive the notions presented in this study. However, the model proposed in this study can also be applied to firms without R\&D departments which are successful in their sectors with significant market share.

Secondly, during the composition of the model, we used entrepreneurship orientation, negative entropy, co-creation, SDL and open innovation concepts. However, innovative and collaborative concepts such as, network governance (Verwaal\&Hesselmans, 2004), new product development (Nambisan, 2002) and long-term relationship orientation (Ganesan, 1994) can also be used in future studies to improve our level understanding in supply chain performance. Additionally, taking significant effect of negative entropy on supply chain performance metrics into consideration, this conspicuous concept, should used in future studies about supply chain, would provide further organizational level of understanding.

In this paper supply chain performance is examined and measured through SCOR attributes. Nonetheless, literature provides a number of supply chain performance measurement methods which can also be used (Torabizadeh, 2014). On the other hand, additional research can be made with the concepts we studied on sustainable supply chain performance (Varsei, 2014).

\section{REFERENCES}

Anderson, B.S., Covin, J.G. and Slevin, D.P., (2009). Understanding the relationship between entrepreneurial orientation and strategic learning capability: an empirical investigation. Strategic Entrepreneurship Journal. 3(3). pp.218-240.

Atuahene-Gima, K., and Ko, A. (2001). An empirical investigation of the effect of market orientation and entrepreneurship orientation alignment on product innovation. Organization science. 12(1). pp.54-74.

Avolio, B.J., Yammarino, F.J., Bass, B.M. (1991). Identifying Common Methods Variance with Data Collected From a Single Source: an Unresolved Sticky Issue. Journal of Management. 17(3). pp.571-587.

Azadegan, A. and Dooley, K.J., (2010). Supplier innovativeness, organizational learning styles and manufacturer performance: An empirical assessment. Journal of Operations Management. 28(6). pp.488-505. 
Bagozzi, Richard P. and Yi, Youjae. (1988). On the Evaluation of Structural Equation Models. Journal of Academy of Marketing Science. 16(1). pp.74-94.

Ballantyne, D. (2004). Dialogue and its role in the development of relationship specific knowledge. Journal of Business \& Industrial Marketing. 19(2). pp.114-123.

Ballantyne, D., and Varey, R. J. (2006). Creating value-in-use through marketing interaction: the exchange logic of relating, communicating and knowing. Marketing theory. 6(3). pp.335-348.

Bigliardi, B., Bottani, E. and Galati, F., (2010). Open innovation and supply chain management in food machinery supply chain: a case study. International Journal of Engineering. Science and Technology. 2(6). pp.244-255.

Bolstorff, P., (2002). How does SCOR measure up. Supply Chain Technology News, pp.22-25.

Borys, B. and Jemison, D.B. (1989). Hybrid agreements as strategic alliances: theoretical issues in organizational combinations. Academy of Management Review. 14(2). pp.234-49.

Bowersox, D. J., Closs, D. J., and Cooper, M. B. (2002). Supply chain logistics management. 2nd Edition. New York, NY: McGraw-Hill.

Battilana, J., Leca, B., and Boxenbaum, E. (2009). How actors change institutions: Towards a theory of institutional entrepreneurship. The Academy of Management Annals. 3(1). pp.65-107.

Callaway, S. K. and Dobrzykowski, D. D. (2009). Service-oriented entrepreneurship: service-dominant logic in green design and healthcare. Service Science. 1(4). pp.225-240.

Cenfetelli, R.T. and Bassellier, G. (2009). Interpretation of Formative Measurement in Information Systems Research. Mis Quarterly. 33(4). pp.689-707.

Chen, Y.C., Li, P.C. and Evans, K.R. (2012). Effects of interaction and entrepreneurial orientation on organizational performance: Insights into market driven and market driving. Industrial Marketing Management. 41(6). pp.1019-1034.

Chesbrough H.W. (2003). The era of open innovation. MIT Sloan Manag. Rev. 44 (3). pp. 35-38.

Chesbrough, H.W. (2012). Open innovation: Where we've been and where we're going. Research Technology Management. 55(4). pp.2027.

Chin, W.W., (1998). The partial least squares approach to structural equation modeling. Modern methods for business research. 295(2). pp.295-336.

Christopher, M. (2011). Logistics \& supply chain management. Fourth Edition. Pearson Education Ltd.

Covin, J.G., Green, K.M. and Slevin, D.P. (2006). Strategic process effects on the entrepreneurial orientation-sales growth rate relationship. Entrepreneurship theory and practice. 30(1). pp.57-81.

Dong, B., Evans, K.R. and Zou, S., (2008). The effects of customer participation in co-created service recovery. Journal of the Academy of Marketing Science. 36(1). pp.123-137.

Dibrell, C. and Moeller, M., (2011). The Impact of a Service-Dominant Focus Strategy and Stewardship Culture on Organizational Innovativeness in Family-Owned Businesses. Journal of Family Business Strategy. 2(1). pp.43-51.

Dyer, J. H. (2000). Collaborative advantage: Winning through extended enterprise supplier networks. Oxford University Press.

Fawcett, S.E., Jones, S.L. and Fawcett, A.M. (2012). Supply chain trust: The catalyst for collaborative innovation. Business Horizons. 55(2). pp.163-178.

Finney, R. Z., Spake, D. F., and Finney, T. G. (2011). Lost in transition? The human influence on marketing's emerging service-dominant logic. Journal of Management and Marketing Research. 6. pp.1-16.

Flint, D. J., and Mentzer, J. T. (2006). Striving for integrated value chain management given a service-dominant logic for marketing. In R. F. Lusch \& S. L. Vargo (Eds). The service dominant logic of marketing: Dialog, debate and directions. pp. 139-149.

Fornell, C. and Larcker, D.F. (1981). Evaluating Structural Equation Models with Unobservable Variables and Measurement Error. Journal of Marketing Research. 18(1). pp.39-50.

Galbraith, J. (2005). Designing the Customer-Centric Organizations. San Francisco.

Ganesan, S. (1994). Determinants of long-term orientation in buyer-seller relationships. the Journal of Marketing. 58(2). pp.1-19.

Goffin, K., Lemke, F., and Szwejczewski, M. (2006). An exploratory study of 'close'supplier-manufacturer relationships. Journal of operations management. 24(2). pp.189-209.

Gok, Tarkan. (2014). A Practice About the Effects of Innovative and Negative Entropic Strategies on Corporate Identity. Halic University, Doctoral Thesis.

Golafshani, Nahid, (2003). Understanding Reliability and Validity in Qualitative Research. The Qualitative Report. 8(4). pp.597-607. 
Grinberg, S. (2007). Pedagogical Risk and Governmentality: Shanty Towns in Argentina in the 21st Century. In trabajo presentado en Risk and Rationalities Conference, Economic \& Social Research Council. pp. 29-30.

Grönroos, C. (2008). Adopting a service business logic in relational business-to-business marketing: value creation, interaction and joint value co-creation. In Otago forum. 2(9). pp.268-287.

Gunasekaran, A., and Ngai, E. W. (2004). Information systems in supply chain integration and management. European Journal of Operational Research. 159(2). pp.269-295.

Halbesleben, J. R. and Whitman, M. V. (2013). Evaluating Survey Quality in Health Services Research: a Decision Framework for Assessing Nonresponse Bias. Health services research. 48(3). pp.913-930.

Hair, Joseph F. Jr., Black, William C., Babin, Barry J. and Anderson, Rolph E. (2010). Multivariate Data Analysis. 7th Edition. Pearson Education. New Jersey.

Hamel, G., Doz, Y., and Prahalad, C. (1989). Collaborate with your competitors. Harvard business review. 67(1). pp.133-139.

Handfield, R.B., Ragatz, G.L., Petersen, K.J. and Monczka, R.M., (1999). Involving suppliers in new product development. California management review. 42(1). pp.59-82.

Harman, H. H. (1976). Modern factor analysis. Chicago, IL: University of Chicago Press.

Henseler, J., Ringle, C. M. and Sinkovics, R. R. (2009). The Use of Partial Least Squares Path Modeling in International marketing. Advances in International Marketing. 20(1). pp.277-319.

Inauen, M., and Schenker-Wicki, A. (2011). The impact of outside-in open innovation on innovation performance. European Journal of Innovation Management. 14(4). pp.496-520.

Jiang, X., Yang, Y., Pei, Y.L. and Wang, G., (2014). Entrepreneurial orientation, strategic alliances, and firm performance: Inside the black box. Long Range Planning. 49(1). pp. 103-116.

Jothimani, D. and Sarmah, S.P., (2014). Supply chain performance measurement for third party logistics. Benchmarking: An International Journal, 21(6), pp.944-963.

Karpen, I. O., and Bove, L. L. (2008). Linking SD logic and marketing practice: Toward a strategic service orientation. In Otago Forum. 2(9). pp. 214-237.

Kast, R. E., and Rosenzweig, J. E. (1974). Organization and management. New York.

Katz, D. and Kahn. R. L. (1978). The social psychology of organizations. 2nd Edition. New York: Wiley.

Kocaoğlu, B., Gülsün, B. and Tanyaş, M., (2013). A SCOR based approach for measuring a benchmarkable supply chain performance. Journal of Intelligent Manufacturing. 24(1). pp.113-132.

Kock, N. (2015). WarpPLS 5.0 User Manual. Laredo. Texas: ScriptWarp Systems.

Kreiser, P. M., Marino, L. D., and Weaver, K. M. (2002). Assessing the psychometric properties of the entrepreneurial orientation scale: A multi-country analysis. Entrepreneurship Theory and Practice. 26(4). pp71-94.

Lamberti, L., and Paladino, A. (2013). Moving forward with service dominant logic: Exploring the strategic orientations of a service-centred view of the firm. International Journal of Business Science and Applied Management. 8(1). pp.1-15.

Lewis, E.F., Hardy, M. and Snaith, B. (2013). An Analysis of Survey Reporting in the Imaging Professions: is the Issue of Non-Response Bias Being Adequately Addressed? Radiography. 19(3). pp.240-245.

Liao, S. H., and Kuo, F. I. (2014). The study of relationships between the collaboration for supply chain, supply chain capabilities and firm performance: A case of the Taiwan' s TFT-LCD industry. International Journal of Production Economics. 156. pp.295-304

Lichtenthaler, U., (2008). Open innovation in practice: an analysis of strategic approaches to technology transactions. IEEE Transactions on engineering management. 55(1). pp.148-157.

Lin, Y., Wang, Y. and Yu, C., (2010). Investigating the drivers of the innovation in channel integration and supply chain performance: A strategy orientated perspective. International Journal of Production Economics. 127(2). pp. 320-332.

Lisboa, A., Skarmeas, D., and Lages, C. (2011). Entrepreneurial orientation, exploitative and explorative capabilities, and performance outcomes in export markets: A resource based approach. Industrial Marketing Management. 40(8). pp.1274-1284.

Lumpkin, G. T., and Dess, G. G. (1996). Clarifying the entrepreneurial orientation construct and linking it to performance. Academy of Management Review. 21(1). pp.135-172.

Lumpkin, G. T., and Dess, G. G. (2001). Linking two dimensions of entrepreneurial orientation to firm performance: The moderating role of environment and industry life cycle. Journal of business venturing. 16(5). pp.429-451. 
Lusch, R. F., Vargo, S. L., and Malter, A. J. (2006). Taking a leadership role in global marketing management. Organizational Dynamics. 35(3). pp.264-278.

Lusch, R. F., Vargo, S. L., and O'Brien, M. (2007). Competing through service: Insights from service-dominant logic. Journal of retailing. 83(1). pp.5-18.

Lusch, R. F. (2011). Reframing supply chain management: a service-dominant logic perspective. Journal of Supply Chain Management. 47(1). pp.14-18.

Madhani, P. M. (2012). Value creation through integration of supply chain management and marketing strategy. The IUP Journal of Business Strategy. 9(1). pp.7-26.

Mascarenhas, O. A., Kesavan, R., and Bernacchi, M. (2004). Customer value-chain involvement for co-creating customer delight. Journal of consumer marketing. 21(7). pp.486-496.

Merz, M. A., He, Y., and Vargo, S. L. (2009). The evolving brand logic: a service-dominant logic perspective. Journal of the Academy of Marketing Science. 37(3). pp.328-344.

Najmi, A. and Makui, A., (2012). A conceptual model for measuring supply chain's performance. Production Planning \& Control. 23(9). pp.694-706.

Nam, K., and Lee, N. H. (2010). Typology of Service Innovation from Service-Dominant Logic Perspective. J. UCS. 16(13). pp.1761-1775.

Nambisan, S. (2002). Designing virtual customer environments for new product development: Toward a theory. Academy of Management Review. 27(3). pp.392-413.

Payne, A. F., Storbacka, K., and Frow, P. (2008). Managing the co-creation of value. Journal of the academy of marketing science. 36(1). pp.83-96.

Peery, N. S. (1975). General systems theory approaches to organizations: Some problems in application. Journal of Management Studies. 12(3). pp266-275.

Pilav-Velić, A., and Marjanovic, O. (2016). Integrating open innovation and business process innovation: Insights from a large-scale study on a transition economy. Information \& Management. 53(3). pp.398-408.

Podsakoff, P.M. and Organ, D.W., (1986). Self-reports in organizational research: Problems and prospects. Journal of management, 12(4), pp.531-544.

Prahalad, C. K., and Ramaswamy, V. (2004). Co-creation experiences: The next practice in value creation. Journal of interactive marketing. 18(3). pp.5-14.

Ramanathan, U., Gunasekaran, A. and Subramanian, N., (2011). Supply chain collaboration performance metrics: a conceptual framework. Benchmarking: An International Journal. 18(6). pp.856-872.

Rauch, A., Wiklund, J., Lumpkin, G. T. T., and Frese, M. (2009). Entrepreneurial orientation and business performance: An assessment of past research and suggestions for the future. Entrepreneurship: Theory and Practice. 33(3). pp.761-787.

Read, S., N. Dew, S. Sarasvathy, M. Song and R. Wiltbank. (2009). Marketing Under Uncertainty: The Logic of an Effectual Approach. Journal of Marketing. 73(3). pp.1-18.

Ren, S. J., Hu, C., Ngai, E. W. T., and Zhou, M. (2015). An empirical analysis of inter-organisational value co-creation in a supply chain: a process perspective. Production Planning \& Control. 26(12). pp.969-980.

Runyan, R., Droge, C. and Swinney, J., (2008). Entrepreneurial orientation versus small business orientation: what are their relationships to firm performance?. Journal of Small Business Management. 46(4). pp.567-588.

Saguy, I. S., and Sirotinskaya, V. (2014). Challenges in exploiting open innovation's full potential in the food industry with a focus on small and medium enterprises (SMEs). Trends in Food Science \& Technology. 38(2). pp.136-148.

Sarasvathy, S. (2008). Effectuation: Elements of Entrepreneurial Expertise, Edward Elgar Publishing, Cheltenham, UK.

Schneider, M., and Somers, M. (2006). Organizations as complex adaptive systems: Implications of complexity theory for leadership research. The Leadership Quarterly. 17(4). pp.351-365.

Seifert, D. (2003). Collaborative planning, forecasting, and replenishment: How to create a supply chain advantage. AMACOM Div American Mgmt Assn. New York.

Shamah, R.A. and Elsawaby, S.M., (2014). Trust as a nucleus key for open innovation. Journal of Business and Retail Management Research. 9(1). pp.110-128.

Shane, S., and Venkataraman, S. (2000). The promise of entrepreneurship as a field of research. Academy of Management Review. 25(1). pp217-226.

Sillanpää, I., (2015). Empirical study of measuring supply chain performance. Benchmarking: An International Journal. 22(2). pp.290-308. 
Simatupang, T.M. and Sridharan, R., (2002). The collaborative supply chain. The International Journal of Logistics Management. 13(1). pp.15-30.

Starik, M., and Rands, G. P. (1995). Weaving an integrated web: Multilevel and multisystem perspectives of ecologically sustainable organizations. Academy of Management Review. 20(4). pp.908-935.

Stephens, S., (2000). The Supply Chain Council and the Supply Chain Operations Reference (SCOR) model: Integrating processes, performance measurements, technology and best practice. Logistics Spectrum. 34(3). pp.16-18.

Stephens, S. (2001). Supply chain operations reference model version 5.0: a new tool to improve supply chain efficiency and achieve best practice. Information Systems Frontiers. 3(4). pp.471-476.

Tenenhaus, M., Vinzi, V. E., Chatelin, Y. M., and Lauro, C. (2005). PLS path modeling. Computational statistics \& data analysis. 48(1). pp.159205.

Theeranuphattana, A. and Tang, J.C., (2007). A conceptual model of performance measurement for supply chains: Alternative considerations. Journal of Manufacturing Technology Management. 19(1). pp.125-148.

Torabizadeh, M. E., Noordin, M. Y., and Awaluddin, M. S. (2014). Performance Measurement System for Sustainable Supply Chain Management. Advanced Materials Research. 845. pp.516-520.

Traitler, H., Watzke, H. J. and Saguy I. S. (2011). Reinventing R\&D in an open innovation ecosystem. Journal of food science. 76(2). pp.R62R68.

Ulrich, K. T., and Ellison, D. J. (2005). Beyond make-buy: Internalization and integration of design and production. Production and Operations Management. 14(3). pp.315-330.

Užienè, L. (2015). Open Innovation, Knowledge Flows and Intellectual Capital. Procedia-Social and Behavioral Sciences. 213. pp.1057-1062.

Van Lancker, J., Wauters, E., and Van Huylenbroeck, G. (2016). Managing innovation in the bioeconomy: An open innovation perspective. Biomass and Bioenergy. 90. pp.60-69.

Vargo, S., F. Lusch. (2004). Evolving to a New Dominant Logic for Marketing. Journal of Marketing. 68(1). pp.1-17.

Vargo, S. L., Maglio, P. P., and Akaka, M. A. (2008). On value and value co-creation: A service systems and service logic perspective. European management journal. 26(3). pp.145-152.

Varsei, M., Soosay, C., Fahimnia, B., and Sarkis, J. (2014). Framing sustainability performance of supply chains with multidimensional indicators. Supply Chain Management: An International Journal. 19(3). pp.242-257.

Waters, D. (2010). Global Logistics: New Directions In Supply Chain Management. 6th Edition. Kogan Page.

Verwaal, E., and Hesselmans, M. (2004). Drivers of Supply Network Governance: An Explorative Study of the Dutch Chemical Industry. European Management Journal. 22(4). pp.442-451.

West, J., Salter, A., Vanhaverbeke, W., and Chesbrough, H. (2014). Open innovation: The next decade. Research Policy. 43(5). pp.805-811.

Wetzels, M., Odekerken-Schroder, G. and Van Oppen, C. (2009). Using PLS Path Modeling for Assessing Hierarchical Construct Models: Guidelines and Empirical Illustration. MIS Quarterly. 33(1). pp.177-196.

Yamazaki, K., Capatina, A., Bouzaabia, R. and Kocoglu, I., (2012). Cross-Cultural Issues Related to Open Innovation in High-Tech Companies from Japan, Romania, Tunisia and Turkey. Revista de Management Comparat International. 13(4). pp.561-573.

Zehir, C., Can, E. and Karaboga, T. (2015). Linking Entrepreneurial Orientation to Firm Performance: The Role of Differentiation Strategy and Innovation Performance. Procedia-Social and Behavioral Sciences. 210. pp.358-367.

Zhou, K. Z., Yim, C. K., and Tse, D. K. (2005). The effects of strategic orientations on technology- and market-based breakthrough innovations. Journal of Marketing. 69(2). pp.42-60.

Zwass, V. (2010). Co-creation: Toward a taxonomy and an integrated research perspective. International Journal of Electronic Commerce. 15(1). pp.11-48. 
Appendix 1

Measures and Items

Construct and Measurement Item

Factor Loadings

Reference

Entrepreneurship Orientation $\overline{\mathrm{X}}=3.69 \sigma=0.85$

Under uncertainty, our company always adopts an adventurous and active attitude.

Our company strongly prefers high-risk projects (with chances of very high return).

Our company always takes bold, wide-ranging strategic actions rather than making minor tactical changes.

When confronted with decisions involving uncertainty, our company always adopts a bold posture to maximize the probability of exploiting opportunities.

Negative Entropy $\overline{\mathrm{X}}=4.01 \sigma=0.59$

In our supply chain, there is a positive and efficient structure that prevents dissolution.

In our supply chain, knowledge is deemed valuable and there are necessary systems to protect it.

There are effective strategies deployed in order to preserve our supply chain.

In our supply chain, technical and technological assets are protected supremely.

In our supply chain, elements that would cause disorder are removed.

In our supply chain, processes are taken under control by creating standard operational procedures.

Systems are developed to restore supply chain balance and stability that can be disrupted time to time.

Co-Creation $\overline{\mathrm{X}}=4.04 \sigma=0.45$

We execute co-creation processes with other supply chain members.

Ideas conveyed from other members of supply chain encourage us in value co-creation.

We plan the value presented to customers with other members of supply chain together.

As members of supply chain, we utilize multiple channels in acquiring customer information.

Other supply chain members concur with us on co-creating the value.

Service Dominant Logic $\overline{\mathrm{X}}=4.20 \sigma=0.55$

Our business objectives are driven primarily by customer satisfaction.

We constantly monitor our level of commitment and orientation to serving customers' needs.

We give close attention to after-sales service.

We measure customer satisfaction systematically and frequently.

Our business strategies are driven by our beliefs about how we can create greater value for customers.

We not only present products to our customers but also services integrated with them.

Open Innovation $\overline{\mathrm{X}}=3.73 \sigma=0.77$

We innovate new products and services with other members of our supply chain.

We include our retailers and suppliers to our innovation processes.

Lin et al. 2010

.720

We do not limit innovation activities to company boundaries, and carry out with other supply chain members.

Gok, 2014

705

37 93 0 2011

We develop special products and services with our supply chain members to our customers.

Supply Chain Performance $\overline{\mathrm{X}}=4.08 \sigma=0.49$

Delivering right order to right customers

Delivering orders to customers at right place

Delivering orders to customers at right quantity

Delivering orders to customers at the requested time

Developed by 
Delivering orders to customers at the requested quality $\quad .699$

Responding to customer-designated supply time $\quad .697$

Responding to customer-designated delivery locations

Responding rapidly to customers given orders $\quad .669$

Flexibility for customer-oriented products or services $\quad .784$

Flexibility for over-volumed customer orders $\quad .805$

$\begin{array}{ll}\text { Flexibility for additional customer-requested delivery locations } & .714\end{array}$

Cost savings in firm's production expenditures $\quad .781$

Cost savings in firm's procurement expenditures $\quad .815$

Cost savings in firm's logistics expenditures $\quad .835$

Cost savings in firm's supply chain management expenditures $\quad .801$

$\begin{array}{ll}\text { Improvements in cash conversion cycle } & .815\end{array}$

Improvements in return-on-assets ratio $\quad .798$

Improvements in capacity usage $\quad .653$

$\begin{array}{ll}\text { Improvements in inventory turnover } & .676\end{array}$

Note: All factor loadings are acquired from SPSS with varimax rotation method. 
Appendix 2

Sample Characteristics

\begin{tabular}{|c|c|c|}
\hline & Frequency & Percentage(\%) \\
\hline \multicolumn{3}{|l|}{ Gender } \\
\hline Male & 130 & 76.0 \\
\hline Female & 41 & 24.0 \\
\hline \multicolumn{3}{|l|}{ Age } \\
\hline $18-25$ & 5 & 2.9 \\
\hline $26-35$ & 89 & 52.1 \\
\hline $36-45$ & 51 & 29.8 \\
\hline $46-55$ & 24 & 14.0 \\
\hline $56+$ & 2 & 1.2 \\
\hline \multicolumn{3}{|l|}{ Education } \\
\hline Associate Degree & 4 & 2.3 \\
\hline Bachelor's Degree & 90 & 52.6 \\
\hline Masters Degree & 69 & 40.4 \\
\hline Ph.D. Degree & 8 & 4.7 \\
\hline \multicolumn{3}{|l|}{ Department } \\
\hline Production & 19 & 11.1 \\
\hline Supply Chain/Logistics & 71 & 41.5 \\
\hline Sales/Marketing & 22 & 12.9 \\
\hline Maintenance/Repair & 4 & 2.3 \\
\hline Research/Development & 24 & 14.0 \\
\hline Procurement & 21 & 12.4 \\
\hline Finance/Accounting & 10 & 5.8 \\
\hline \multicolumn{3}{|l|}{ Position } \\
\hline Engineer, Chief, Specialist & 59 & 34.5 \\
\hline Manager & 71 & 41.5 \\
\hline Director & 23 & 13.5 \\
\hline Director General/Vice D.G. & 14 & 8.2 \\
\hline Owners & 4 & 2.3 \\
\hline \multicolumn{3}{|l|}{ Personnel in the Firm } \\
\hline $1-9$ & 0 & 0.0 \\
\hline $10-49$ & 0 & 0.0 \\
\hline $50-249$ & 55 & 32.2 \\
\hline $250+$ & 116 & 67.8 \\
\hline \multicolumn{3}{|l|}{ Years the Firm Operates } \\
\hline Less than a Year & 0 & 0 \\
\hline $1-5$ & 4 & 2.3 \\
\hline $6-10$ & 21 & 12.3 \\
\hline $11-15$ & 10 & 5.8 \\
\hline $16-20$ & 9 & 5.3 \\
\hline $20+$ & 127 & 74.3 \\
\hline \multicolumn{3}{|l|}{ Sector of the Firm } \\
\hline Food Production & 28 & 16.4 \\
\hline White Appliances & 11 & 6.4 \\
\hline Automotive & 28 & 16.4 \\
\hline Plastics/Packaging & 13 & 7.6 \\
\hline Chemicals & 11 & 6.4 \\
\hline Textile & 9 & 5.3 \\
\hline Construction & 6 & 3.5 \\
\hline Electricity/Electronics & 10 & 5.8 \\
\hline Information Technology & 7 & 4.1 \\
\hline Heating/Cooling & 4 & 2.3 \\
\hline Logistics & 13 & 7.6 \\
\hline Medicals & 7 & 4.1 \\
\hline Defence & 15 & 8.8 \\
\hline Other(Aviation, Telecom., Durables, & 9 & 5.3 \\
\hline
\end{tabular}

DOI: 10.17261/Pressacademia.2017.457 
Forest Products)

\section{Position of the Firm in Supply Chain}

Retailer

Distributer/Wholesaler

Manufacturer

74.9

First Tier Supplier

5.8

Second Tier Supplier

4.7

Logistics Service Provider

7.6

Total

171

100 